\title{
Remittance-Growth Nexus in Ethiopia: An Evidence from ARDL Bound Testing Approach
}

\author{
Yohannis Bekele Kemiso \\ Department of Economics, Ambo University, PO box 19, Ambo, Ethiopia
}

\begin{abstract}
The effect of international remittance inflows on economic growth has become a debating topic among policymakers. This study has used the data of 1980 to 2018. The result of the analysis revealed that the Long-run and short-run impact of remittance is negative at $1 \%$ and $5 \%$ significant level. This implies, the consumption compensatory behavior of remittance income. Other determinants of growth; such as gross capital formation, gross national saving, and foreign direct investment are appeared to be positive at $<5 \%$ significant level impacting growth in Ethiopia both in the long run and short run except for the short-run result of gross national saving is not available. While external debt and terms of trade were significant and negatively associated with growth in both the long run and short run at $1 \%$ significant level. The policy implications are, the development agents need to focus on controlling the informal flow of money (black market) through reducing transaction costs and training households receiving remittance to divert from consumption to investment. Thus, remittance inflows must be invested in the productive sector before it can positively impact economic growth and thus, for the ease of the more investment climate the better economic development.
\end{abstract}

Keywords: ARDL, Economic Growth, ECM, Ethiopia, Remittance.

DOI: $10.7176 / \mathrm{JESD} / 12-23-03$

Publication date: December $31^{\text {st }} 2021$

\section{Introduction}

From economic growth point of view, fundamentals of economic growth in developing countries have been the subject of continuous debate in macroeconomic literature. While researchers like Solow 1956; Romer 1986; Keynesians, concentrated their research focus in search of economic growth variables on physical capital accumulation, Foreign Direct Investment, openness, investment and Finance respectively. Comparably a little attention has been accounted to remittance flows as potential source of economic growth especially in developing countries. However, remittances are a vital supply of financial gain for economy of the country, specifically in Africa. Studies have shown that remittances contribute to impoverishment reduction in home countries which has currently become unremarkable used term, that is but hardly ever outlined (Kratou \& Gazdar, 2016).

Moreover, remittances have tried to be additional property supply of foreign currency for developing countries than alternative capital inflows like foreign direct investment, debt or official development aid. However, the nexus between remittances and development remains advanced, particularly with regards to the movement of individuals, that contributes to the spread of global interdependence at all levels- social, economic and political. (Koehler et al., 2010).

Several positive measures are taken by the government of Ethiopia in recent years to boost the operations and flow of formal remittances, yet on scale back the prices of transfers and increase access to international remittance services. Some point out remittances as a part of a wider development and financial inclusion agenda, whereas others address remittances and diaspora development directly. the most initiatives and directives of note are expressed by the growth and transformation plan II, 2015/16-2019/20 the growth and Transformation Plan (GTP) what is a national five-year plan created by the Ethiopian government to boost the country's economy by achieving a projected value growth of 11-15 per cent per annul from 2010 to 2015. GTP II, that was published in May 2016 with a number of the key priorities includes; modernizing the agriculture sector, increasing industrial development with a primary target lightweight producing, shifting to export development, and increasing financial access levels. GTP II is a very important milestone towards realizing Ethiopia's vision of changing into a middle-income country by 2025. Among alternative areas, GTP II recognized remittances joined of the contributory factors for the positive development witnessed in respect to the balance of payments of the country. The National Foreign Affairs Policy and National Security Policy and Strategy conjointly acknowledge the role of the Ethiopian diaspora in terms of causation remittances, investment, and information transfer. (Isaacs, 2017).

According to the file of Ratha (2014), the typical quantity of money a remittance sender sends to developing international locations is $\$ 100-\$ 300$ per month. Approximately 80 to $90 \%$ of remittances go closer to consumption, while 10 to 20 percent are used for formal or informal financial savings and investments. (World Bank, 2014), family surveys in Ethiopia on remittances additionally shows that, about $57 \%$ of the money used for daily expenses, $29 \%$ is used for university education, $9 \%$ for small business, $4 \%$ for saving account and $1 \%$ for housing purposes. Evidence suggests that informal networks stay an outstanding approach for Ethiopians to send money home. The maximum number of remittances 78 per cent of the total might presently be sent through informal channels in 
some corridors. This represents both opportunities and challenges (Leon, 2017).

Lack of access to services within the send and receive markets, high direct and indirect prices related to formal channels, irregular migration, the existence of parallel market exchange rates, and regulatory barriers for unsupported migrants contribute to the high level of informal transfers. Informal flows not solely represent a loss of interchange for the government of Ethiopia, however reduce the opportunities to encourage investment; are a risk to the consumer, and prevent the government from following flows for Anti-Money laundering (AML) and combating the funding of coercion (CFT) functions (Isaacs, 2017).

There's no universal agreement on how to measure the power of international remittances to the economies of developing countries. These information limitations are attributed to the improper procedure of capturing remittance statistics. Also, variables of economic growth aren't agreeing for several researchers. All these provide the requirement to keenly analyze and perceive the potential result of international remittance on economic growth (Beatrice \& Samwel, 2015). The structural specificities of a selected country's economy, the broader institutional and political surroundings, the standard of establishments and their development level, influence the manner remittances affect a country's economy (Richard et al., 2017).

Since the early reform of the Ethiopian economy, several researchers have tried to access the results of remittances on economic growth and come up with different results. In this manner most studies were conducted at micro level in different regions of Ethiopia on impoverishment and consumption behavior of household using different methods and instruments; the result reveals that remittance has adverse effect on poverty and increase consumption behavior (Berhe, 2012; Lisa, 2012; Jibril \& Leta, 2016; Tesfaye, 2018). However, the researchers have not reached on consensus whether or not and how the remittance is used has a significant impact on economic growth for the Ethiopian economy which is the gap in remittance kinds of literature.

The study at macro level Tassew and Rao (2016) used a time series data for the period 1981-2012 using ARDL model by together with some explanatory variables like remittance, fixed capital formation, secondary school enrollment rate and total government expenditure, found a short-run positive significant impact of remittances on economic growth, whereas it affects the economy negatively in the long run. They additionally did not embrace variable like the foreign direct investment that do have the power within the analysis of growth and remittance relationship. The previous studies, Mikias (2014), Wondaferahu et al. (2015) conducted at macro level lacks the basic channels through which remittance impact economic growth. So, this study is to investigate these gaps in the Ethiopian economy. In addition, this study is new as Ethiopian context that uses fundamental factors of economic growth and the channels through which remittance can affect output during which it uses time series data 1980-2018, and examining the result of remittance on economic growth

\section{Theoretical and Empirical Review}

Since the emergency of migration economics different scholars are seeking the country's benefits from migrants from emigration and immigration, beyond these, the idea of remittance become debating agenda and resulted in controversial findings among economists. The previous result has segregated into optimists (positive effect of remittance on economic growth), pessimists (negative or no effects of remittance on economic growth) and pluralistic (mixed result of remittance on economic growth).

\subsection{Positivists View of Remittance on Economic Growth}

There are numerous empirical evidences about the possible effects of remittances to spur economic growth, through the channels of consumption, savings, investment. In this regard, several studies recognized the positive impact of remittances thereby accelerating investment in Morocco, India and Pakistan (Lucas, 2005) and in Mediterranean countries (Glytsos, 2002). Ratha (2003) concludes that remittances increase the consumption level of rural households, which might have substantial multiplier effects, because they are more likely to be spent on domestically produced goods. Adams and Page (2005), Acosta et al. (2008) and World Bank (2014) argued that migrant remittances impact positively on the balance of payments in many developing countries as well as enhance economic growth, via their direct effect on savings and investment in human development and, indirect effects on consumption.

Guilamo \& Ruiz-Arranz (2005) had worked on data set of more than 100 developing countries from 1975 to 2002 and found that remittances can enhance economic growth only in less financially developed countries. The positive developmental effects of remittances focus on the multiplier effects of consumption Stahl and Arnold (1986), development of the financial institutions that handle remittance payments Aggarwal et al. (2006), use of remittances as foreign exchange (Ratha, 2005) and the role of remittances as an alternative to debt that helps alleviate individuals credit constraints in countries where micro-financing is not widely available (Guilamo \& Ruiz-Arranz,2006). Based on Guilamo \& Ruiz-Arranz (2005) remittances improve credit constraints on the poor, resize the allocation of capital, substitute for the misspecification of financial development and thus speed up economic growth. Iqbal and Sattar (2005) found that in the absence of remittances, the exchange rate, monetary and fiscal policies will become undermined. 
Rao and Hassan (2009) found the effects of remittances on growth by using the Solow growth model, showing that, migrant remittances have positive but marginal effect on growth. World Bank (2014) and IMF (2005) findings show that remittances indirectly increase the growth rate by reducing output volatility. Nsiah and Feyisa (2011) had shown the economic growth-remittances nexus for developing countries implies the positive relationship between remittances and economic growth throughout the whole group. Yasser et al. (2012) also suggested that remittance can limit strain to improve the great of insurance policies and institutions by using making recipients to rely much less on government benefits.

\subsection{Negativists View of Remittance on Economic Growth.}

Lipton (1980), Brown and Ahlburg (1991) argued that remittances undermine productivity and growth in lowincome countries because they are readily spent on consumption likely to be dominated by foreign goods than on productive investments.

Amuedo-Dorantes and Pozo (2004), Lopez et al. (2007) got those remittances, like capital flows can appreciate the real exchange rate in recipient economies and therefore divert a resource allocation from the tradable to the non-tradable sector which can highly increase imports (Acosta et al., 2008). Glytsos (2005) found for the study that the impact of remittances on growth is partial and, in several years, negative impact of remittances to growth was familiar across the period. Rodrik (2007) revealed evidence that the real exchange rate appreciation decreases long-term economic growth, even for developing countries, for those countries tradable goods production suffers disequilibrium as a result of weak institutions and market failures.

Lartey et al. (2008) Empirical results also indicate that remittances may indirectly affect real exchange rate leading to the "Dutch Disease" phenomenon, where remittances inflow causes a real appreciation, or postpones depreciation, of the exchange rate. Exchange rates appreciate in countries with large remittances which will in turn hurt the economic growth (Lopez et al., 2007; Acosta et al., 2009).

Gibson and McKenzie, (2012) the brain drain is one of the aspects considered, where emigration of the educated leads to a loss that is not offset by the benefits associated with remittances (Acosta, 2006). The developing countries are drained of their human capital resources when educated inhabitants emigrate. Developmental pessimistic theory implies that the poorest do not have enough money to emigrate because of the costs associated with emigration, such as traveling costs (Adenutsi, 2010; Chami et al., 2008; de Haas, 2007). This would mean that remittances could increase the income gap in developing countries even further. Also, it is argued that remittances would not be spent on developing enhancing investment, as the optimistic view would imply If the aim, when remitting, is to invest in the receiving country it means that the recipients make the investment decisions on behalf of the sender. The recipient might not be as skilled as domestic financial intermediaries; therefore, the investment is less likely to be successful (Barajas et al., 2009; Chami et al., 2008). Money would rather be spent on consumption or non-productive investments such as real estate and rarely in productive enterprises (Adenutsi, 2010).

Based on Gautam, D. (2017) another aspect to consider is that the level of corruption might increase with remittances (Chami et al., 2008). The reasoning is that income from remittances makes government corruption less costly for the households in the receiving country and thereby corruption increases (Gautam, 2017). The receiving remittances will work as a buffer between the inhabitants and the government and thereby the problems associated with moral hazard occur from this perspective remittances are harmful that diminish the output (Marson \& Subramaniam, 2018).

\subsection{Pluralistic View of Remittance on Economic Growth.}

The Developmental Pluralistic View arose due to the fact that since the 1980s. According to this theory there are not strictly negative nor positive results of remittances in the remittance receiving countries, the problem is extra complex. There is a need for new theories involving the more than one way, in which remittances ought to affect the recipient economies, to be in a position to understand the complex relationship between migration and financial increase (Taylor, 2002). The pluralistic view pursuits to link motives and consequences of migration more explicitly, in which each high-quality and poor results on economic growth are feasible (De Haas, 2007). They argue that due to the fact of the complexity of remittances and development, there is a need of more dynamic grasp of the relationship between them. Neither the optimistic nor the pessimistic view gives this (Adenutsi, 2010). According to this idea the crucial query is now not whether migration has a strictly bad or fine have an impact on development, the consequences of remittances are hence context-dependent (de Haas, 2007; Taylor, 2002). No overarching concept can be applied to, and explain, each and every outcome.

\section{Methodology}

This study has used annual time series data of Ethiopia ranging from 1980 to 2018. The choice of data is in accordance with the accessibility of data for all variables under consideration. The appropriate data for this study is taken from World Bank (WB, 2019) data base, UNCTAD, 2019 (United Nation Conference on Trade and 
Development) and National Bank of Ethiopia (NBE, 2019) which are perceived to be relevant and reliable. further, a constant 2010 USD is used as a base year for real GDP and Inflation Rate. The data was quantitative and secondary source.

After reviewing the theoretical and empirical work, the model to examine the impact of remittances on economic growth is derived using the production function framework. Putting the production function in general form as follows:

$Y=f(A, L, K)$

Where $\mathrm{Y}$ is the real gross domestic product, $\mathrm{L}$ is the total labor force and $\mathrm{K}$ is the capital stock. The variable $\mathrm{A}$ captures the total factor productivity (TFP) effect on the growth in output not accounted for by increasing in factor inputs ( $\mathrm{L}$ and $\mathrm{K}$ ). According to the new (endogenous) growth theory, $\mathrm{A}$ is endogenously determined by economic factors and can be specified using observable factors. Lucas (1988), Barro (1990), Adenutsi (2002) and Adenutsi (2011) showed the effect of remittances on economic growth can also be formulated within the endogenous growth model setup (Abdullatif et al., 2013). If remittance is spent on investment, endogenous growth model provides the channel through which remittances could promote economic growth (Romer 1990) Therefore, based on the arguments mentioned above, TFP can be formulated simply as:

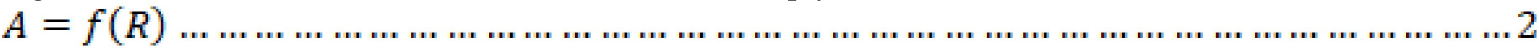

In conclusion, following the above explained arguments and formally stating the equations using Cobb-Douglas production function in which output is a function of physical capital $(\mathrm{K})$ and labor force $(\mathrm{L})$;

$Y=A K^{a} L^{1-a} e^{U}$

Taking the natural logarithm transformation of equation 3 both sides and expanding it to time dimension gives:

$\ln \left(Y_{t}\right)=\ln \left(A_{t}\right)+a \ln \left(K_{t}\right)+(1-a) \ln \left(L_{t}\right)+U_{t}$

Since A is total factor productivity (TFP) which is in turn determined by the available stock of Human capital (H) and Remittance income can replace factor productivity, by taking the natural logarithm of the function which can be stated as:

$\ln \left(A_{t}\right)=b_{0}+b_{1} \ln \left(R E M_{t}\right)$ .5

By Substituting equation (5) into equation (4);

$\ln \left(Y_{t}\right)=b_{0}+b_{1} \ln \left(R E M_{t}\right)+a \ln \left(K_{t}\right)+(1-a) \ln \left(L_{t}\right)+U_{t} \ldots \ldots \ldots \ldots \ldots \ldots \ldots \ldots \ldots \ldots$

Replacing $\ln \left(\mathrm{Y}_{\mathrm{t}}\right)$ by $\ln \left(\mathrm{RGDP}_{\mathrm{t}}\right)$ and capturing the extended variables those can affect economic growth in addition to international remittance have stated as:

$$
\begin{aligned}
\ln \left(R G D P_{t}\right)= & b_{0}+b_{1} \ln \left(R E M_{t}\right)+b_{2} \ln \left(G C F_{t}\right)+b_{3} \ln \left(G N S_{t}\right)+b_{4} \ln \left(F D I_{t}\right)+b_{5} \ln \left(D B T_{t}\right) \\
& +b_{6} \ln \left(T O T_{t}\right)+b_{7} \ln \left(I N R_{t}\right)+U_{t} \ldots \ldots \ldots \ldots \ldots \ldots \ldots \ldots \ldots \ldots
\end{aligned}
$$

Where $\ln \left(\mathbf{R G D P}_{\mathbf{t}}\right)$ is natural $\log$ of Real Gross Domestic Product at a time $t, \ln (\mathbf{R E M})$ is natural $\log$ of remittance at a time $t, \ln (\mathbf{G C F} \mathbf{t})$ is natural $\log$ of gross capital formation at a time $t, \ln \left(\mathbf{G N S}_{\mathbf{t}}\right)$ is natural $\log$ of gross national saving at a time $t, \ln \left(\mathbf{F D I} \mathbf{I}_{\mathbf{t}}\right)$ is natural $\log$ of foreign direct investment at a time $t, \ln \left(\mathbf{D B} \mathbf{T}_{\mathbf{t}}\right)$ is natural $\log$ of external debt at a time $t, \mathbf{I N R}$ is inflation rate at time $t$, and $\ln \left(\mathbf{T O T}_{\mathbf{t}}\right)$ is natural $\log$ of terms of trade proxied by the ratio of Price of Export to Price of Import at a time $t$ and $e_{t}$ is error terms at a time $t$ capturing unexplained position and it follows the assumption of Least square method, iid $\left(0, \sigma^{2}\right)$. finally, the $b_{1}, \ldots b_{6}$ are coefficients of the respective variables. The study had used an auto-regressive distributed lag (ARDL) bound testing approach attributed to (Pesaran, 2001). This approach is chosen as a result of it's got some superior advantages over the antecedently mentioned methods.

Firstly, as the name suggests, this approach permits both the dependent and independent variables to enter the model with lags, thereby permitting the past values of variables to determine its present values. This flexibility in terms of the structure of lags of the regressors is especially plausible as a result of reactions to a change in every variable is also completely different betting on varied factors and in some cases they'll reply to the changes in underlying factors with a lag; so there's typically no reason to assume that everyone regressors ought to have an equivalent lags as suggested by the co-integration var models, wherever different lags for various variables don't seem to be permissible (Pesaran et al., 2001).

Secondly, this methodology is applicable regardless of whether or not the regressor are I (1), I (0) or reciprocally co-integrated and with the exception of I (2), which means that there's no need to have previous testing of the order of integration of the variables, in contrast to the other approaches. Besides, endogeneity and serial correlation issues, that exists in several empirical studies, and inability to check hypothesis on the estimated coefficients within the long run related to Engle and granger (1987) methodology is avoided (Pesaran \& Shin, 1999).

\subsection{Long Run Model presentation}

The long run estimation is once tasted after ARDL model, for the result of the F-statistics and t-Statistics passes above the upper bound critical value, it realizes the existence of long run relationship and then the long run model 
will be estimated by OLS. For further realization of the long run existence, one should estimate the long run model by Least Square method and check for the stationarity of its residual weather it is stationary at level, to confirm it again the residual must be stationary at level.

$$
\begin{aligned}
\operatorname{lnRGDP}_{\mathrm{t}}= & \beta_{0}+\varphi_{11} \operatorname{lnRGDP}_{\mathrm{t}-1}+\varphi_{21} \operatorname{lnREM}_{\mathrm{t}-\mathrm{i}}+\varphi_{31} \operatorname{lnRGCF}_{\mathrm{t}-1}+\varphi_{41} \operatorname{lnRGNS}_{\mathrm{t}-1} \\
& +\varphi_{51} \operatorname{lnFDI}_{\mathrm{t}-1}+\varphi_{61} \mathrm{INR}_{\mathrm{t}-1}+\varphi_{71} \operatorname{lnTOT}_{\mathrm{t}-1}+\varphi_{81} \operatorname{lnDBT}_{\mathrm{t}-1} \\
& +\mu_{1 \mathrm{t}} \ldots \ldots \ldots \ldots \ldots \ldots \ldots \ldots \ldots \ldots \ldots \ldots \ldots \ldots \ldots \ldots \ldots \ldots \ldots \ldots \ldots \ldots \ldots \ldots \ldots \ldots \ldots \ldots \ldots \ldots \ldots \ldots \ldots \ldots \ldots \ldots \ldots \ldots \ldots \ldots \ldots \ldots \ldots \ldots \ldots \ldots \ldots \ldots
\end{aligned}
$$

\subsection{Short Run Model presentation}

Then after, the short run dynamics of the model by estimating the Error Correction Dynamics associated with the long run estimates; This model is

$$
\begin{aligned}
& \Delta \operatorname{lnRGDP} P_{\mathrm{t}}=\beta_{\mathrm{o}}+\sum_{\mathrm{i}=1}^{\mathrm{p}} \delta_{1 \mathrm{i}} \Delta \operatorname{lnRGDP_{\mathrm {t}-1}}+\sum_{\mathrm{i}=0}^{\mathrm{q}} \delta_{2 \mathrm{i}} \Delta \ln \operatorname{REM}_{\mathrm{t}-\mathrm{i}}+\sum_{\mathrm{i}=0}^{\mathrm{q}} \delta_{3 \mathrm{i}} \Delta \ln \mathrm{GCF}_{\mathrm{t}-\mathrm{i}} \\
& +\sum_{\mathrm{i}=0}^{\mathrm{q}} \delta_{4 \mathrm{i}} \Delta \operatorname{lnGNP_{\mathrm {t}-\mathrm {i}}}+\sum_{\mathrm{i}=0}^{\mathrm{q}} \delta_{5 \mathrm{i}} \Delta \ln \mathrm{FDI}_{\mathrm{t}-\mathrm{i}}+\sum_{\mathrm{i}=0}^{\mathrm{q}} \delta_{6 \mathrm{i}} \Delta \mathrm{INR}_{\mathrm{t}-\mathrm{i}}+\sum_{\mathrm{i}=0}^{\mathrm{q}} \delta_{7 \mathrm{i}} \Delta \operatorname{lnTOT_{\mathrm {t}-\mathrm {i}}}
\end{aligned}
$$

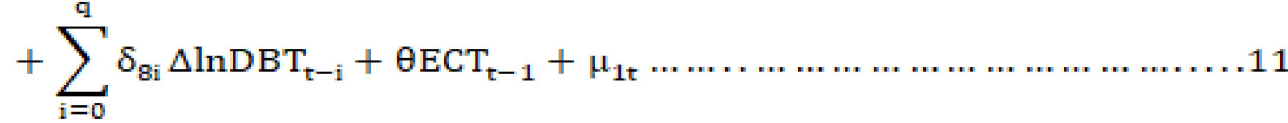

$\theta=\left(1-\sum_{i=1}^{p} \pi_{i}\right)$, speed of adjustment parameter with a negative sign.

$\mathrm{ECT}=\left(\operatorname{lnRGDP} \mathrm{t}_{\mathrm{t}-\mathrm{i}}-\gamma \mathrm{X}_{\mathrm{t}}\right)$, the error correction term is the extracted residuals from the residuals from the regression of the long run equation, and $X_{t}$ represents regressors at time $t$.

$\gamma=\frac{\sum_{\mathrm{i}=1}^{\mathrm{q}} \delta_{\mathrm{i}}}{\beta}$ is the long run parameter

Where: $E C T_{t-1}$ represent the error correction term that will be obtained from ARDL long run dynamics of the model and it is expected to have negative sign showing the eliminating speed of the model. In other words, it is the speed of adjustment to restore equilibrium in the dynamics model (how quickly the variables converge to equilibrium aftershocks).

\section{Result and Discussion}

Every variable become stationary once they are first differenced. This indicates that none of the above variables are integrated of order two (I (2)), which is a pre-condition to use ARDL model. The unit root test result at both ADF and PP have shown I (1) order stationary except for inflation rate (INR) which is stationary at I (0) order, as a result, Auto-regressive Distributed Lag to Bound testing approach is the right technique to apply in this scenario (see Table 1 in appendix). In economics the dependence of variable $Y$, on another variable $X$, is rarely instantaneous, very often $\mathrm{Y}$ responds to $\mathrm{X}$ with a lapse of time in which it is called a lag. In annual time series data too, many lags lead to lose of degrees of freedom, as degrees of freedom is decreasing, the model become suffer from multicollinearity, serial correlation in the error terms and misspecification problems. For selecting appropriate number of lags there is no fast and hard rule on the choice, it is basically an empirical issue; so far, the number of lags for annual data is small which is 1 or 2 ; quarterly data 1 to 8 is appropriate and monthly data 6,12 or 24 can be used given sufficient data points. The easiest way out of this quagmire, is to decide using a criterion like Akaike, Schwarz and Hannan, but choosing the model that gives the lowest values of these criteria (rule-ofthumb), economists use Akaike Information Criteria most often for its lower value, so econometric packages can easily compute these optimal lag lengths (Gujarati, 2004; Asteriou, 2007) see Table 2 in appendix.

See Table 3 in appendix. Remittance (InREM): The estimated long run coefficient for remittance shows that remittance has negative and significant $(\mathrm{p}<1 \%)$ effect on economic growth during the study period. With 0.089 elasticity, treating other variable unchanged, a 10 percent increase in remittance inflow which leads to an average of 0.89 percent decrease in real GDP. These have proved through the corridor that Remittances can reduce labor supply and create a culture of dependency that inhibits the potential economic growth. This result is consistence along with the previous empirical studies with different theoretical arguments and empirical justification (Kapur, 2004; Dilip Ratha, 2007; Abdih et al., 2008; Edwards, 2010; Jawaid and Raza, 2012; Tassew, 2016; Uprety, 2017). Moreover, a large part of remittances received in less developed countries are spent on consumption likely to be dominated by foreign goods than on productive investment. Therefore, these remittances undermine productivity and growth, and some authors argue that remittances may reduce recipients' motivation 
to work El Hamma (2017), creating permanent financial dependency, and slowing down economic growth (Chami et al., 2003). For Elu and Price (2012), remittances can be used to finance terrorism, therefore inhibiting economic growth.

(See table 4 In appendix). The coefficient of the lagged error-correction term is significant at 1\% significant level with the expected sign (i.e., Negative), which confirms the result of the bounds test for co-integration. Its value is found -0.72 which implies that the speed of adjustment to equilibrium after a shock is high. Approximately $72 \%$ of disequilibria of the previous year shock converge back to the long-run equilibrium in the current year. Such highly significant Error correction term is another proof for the existence of a stable, long-run relationship among the variables (Banerjee et al., 1993). Most of the results are similar in both long-run and short-run.

Remittance ( $\triangle$ InREM): Similarly, the result for short run for remittance is negative like the long run coefficient which is statistically significant at $1 \%$ level. The estimated coefficient shows that an increase by $10 \%$ in remittance resulted economic growth to decrease by $0.5 \%$, treating others constant. The negative result of remittances on output is mainly associated with consumption smoothing and fulfilling basic need, as it is obvious that most of the remittance recipients' families are known by their nature of consumption volatility, the remittance can replace the government expenditure for education and subsidies. This result is similar to the study by Qayyum et al. (2008), Waheed and Aleem (2008) both in the case of Pakistan as well as the study conducted by Isaac (2017) and Mikias (2014) in the case of remittance receivers in Ethiopia, where about $60 \%$ of remittance income received by households is meant for daily consumption and $29 \%$ for education and other are $10 \%$. Burgess and Haksar (2005) found evidence of a stabilizing impact of remittances on private consumption in Philippines.

\section{Conclusions and Recommendations}

Remittances lift people out of poverty but recipients of remittances are not automatically turned into entrepreneurs, they perhaps use it at the time of hardship and different ceremonies which is unproductive and not part of economic growth. So, the possible suggestions to recover the bad side of remittances are; Case studies and improved household statistics could play a crucial role here. When more is known about remittances at a household level, policymakers are initiated to focus their efforts on finding ways to channel remittances into uses that do enhance economic growth. Finally, the study recommend that remittance inflows must be invested in the productive sector before it can positively impact economic growth.

\section{References}

Abdih Y., Chami R., Dagher J. and Montiel P. (2008). Remittances and Institutions: Are Remittances a Curse? IMF working paper No: 29. International Monetary Fund, Washington DC.

Acosta, P. Calderon, C. Fajnzylber, P and Lopez, H. (2008), 'What is the impact of international remittances on poverty and inequality in Latin America?', World Development, Vol. 36, No. 1, pp. 89-114.

Adams, R.H. and J. Page, 2005. International Migration, Remittances and Poverty in Developing Countries. World Bank Policy Research Working Paper 3179.

Adenutsi D.E \& Balde.Y. (2010). Do International Remittances promote human development in poor countries? Empirical evidence from Sub-Saharan Africa. In the International of Applied Economics and Finance (pp. 31-45).

Adenutsi DE, 2010. Do international remittances promote human development in poor countries? Empirical evidence from Sub-Saharan Africa, International Journal of Applied Economics and Finance, Vol. 4, No. 1, pp. pp. 31-45.

Agarwala, R. (1983, 2006), Remittance "Price Distortions and Growth in Developing Countries," World Bank S. Working Papers, 575. Washington D.C.: The World Bank.

Amuedo-Dorantes, C., and Pozo, S. (2004). Workers' Remittances and the Real Exchange Rate A Paradox of Gifts. World Development working paper, 32 1407-1417.

Asteriou, D. and Hall, S. (2007) Applied Econometrics A Modern Approach. Palgrave Macmillan, New York.

Banerjee A, Dolado J, Galbraith J and Hendry D. 1993. Co-integration, Error Correction, and the Econometric Analysis of Non-stationary Data. Oxford, Oxford University Press.

Barajas A. et al. (2009, 2012). Workers' Remittances: An Overlooked Channel of International Business Cycle Transmission? International Monetary Fund.

Beatrice Njeri Mwangi \& Samwel N. Mwenda. (2015). The effect of International Remittance on Economic Growth Kenya (un published).

Berhe, M. (2012). The Effect of International Remittances on Poverty and Inequality in Ethiopia. (unpublished)

Burcak p. (2018), The Impact of Workers' Remittances on Economic Growth: Panel Data Approach for Selected Country Group: Applied Economics and Finance, Vol. 6, No. 1; Turkey, ISSN 2332-7294 E-ISSN 2332-7308, URL: http://aef.redfame.com.

Chami, Ralph, Connel Fullenkamp, and Samir Jajah, 2003, “Are Immigrant Remittance Flows a Source of Capital for Development?” IMF Working Paper 03/189 (Washington: International Monetary Fund). 
Chami, Ralph, Dalia Hakura and Montriel, P. (2009. Remittances: An Automatic Stabilizer? IMF working paper $09 / 91$.

Commander, Simon, Mari and Alan (2008), "The brain drains: Curse or boon? A survey of the literature," Challenges to Globalization: Analyzing the Economics, University of Chicago Press, pp. 235-278.

Dani Rodrik (2007), Normalizing Industrial Policy: Commission on Growth and development; Working Paper No.3.

Das, A. and Serieux, J., (2010). Remittances and Reverse Flows in Developing Countries, In IDEAs Working Paper Series, No. 02/2010.

de Haas H, 2007. Remittances, Migration and Social Development -A Conceptual review of the literature, 34, United Nations Institute for Social Development. Social Policy and Development Programme.

Dickey, D. A., \& Fuller, W. A. (1979). Distribution of the estimators for autoregressive time series with a unit root. Journal of the American statistical association, 74(366a), pp. 427-431.

Edward J. Taylor (2002). The New Economics of Labor Migration and the Role of remittances in the Migration: Journal of International Migration; https://doi.org/10.1111/1468-2435.00066.

Edwards, T. (2010). Do Remittances Promote More Economic Growth than Foreign Aid in Latin American and Caribbean Countries? 40.

Engle, R. and Granger, C.W.J. (1987) Cointegration and error correction: representation, estimation and testing. Journal of Econometrics, Vol. 55, pp. 252-276.

Gautam, D. (2017), "Remittance inflows and starting a business", Journal of Entrepreneurship and Public Policy, Vol. 6 No. 3, pp. 290-314. https://doi.org/10.1108/JEPP-D-17-00002

Glytsos, N.P. (2002), "The Role of Migrant Remittances in Development: Evidence from Mediterranean Countries," International Migration, 40(1): 5-26

Golitsis, P., Avdiu, K., \& Szamosi, L. T. (2018). Remittances and FDI effects on economic growth: A VECM and GIRFs for the case of Albania. Journal of East-West Business. https://doi.org/10.1080/10669868.2018.1435432

Guha P, 2013. Macroeconomic Effects of International Remittances: The Case of Developing Economies. Economic Modelling, pp. 292-305.

Giuliano, P. and M. Ruiz-Arranz (2005, 2006), "Remittances, Financial Development, and Growth,” IMF Working Paper 05/234. Washington D.C.: International Monetary Fund.

Haas, H. D. (2007). Remittances, Migration and Social Development. United Nations Research Institute for Social Development, 34.

Harrod, R. (1939) “An Essay in Dynamic Theory,” Economic Journal, 49, 14-33.

Haussmann, R., Hwang, J., \& Rodrik, D. (2007). What you export matters. Journal of Economic Growth, 12, 125. https://doi.org/10.1007/s10887-006-9009-4

Ibrahim ISSIFU (2018) The Impact of Remittance on Domestic Investment: The Role of Financial and Institutional Development in Five Countries in Sub-Saharan Africa: Forum of International Development Studies; ISSN 2189-9126

IMF. (2005). Remittance impact of Economic Growth. World Economic Outlook.

Isaacs, L. (2017). Scaling up formal remittances to Ethiopia. International Organization for Migration.

Jibril Haji \& Leta Sera. 2016. Impact of International Remittances on Poverty Reduction in South-West Ethiopian: Evidence from Jimma Zone. Global Journal of Management and Business Research: Economics and Commerce. Retrieved from Online ISSN: 2249-4588 \& Print ISSN: 0975-5853.

JU Elu, GN Price (2012), Remittances and the financing of terrorism in sub-Saharan Africa: 1974-2006, Peace Economics, Peace Science and Public Policy 18 (1).

Gibson, John and David McKenzie, (2012) “The Economic Consequences of 'Brain Drain' of the Best and Brightest: Microeconomic Evidence from Five Countries," Economic Journal.

Johansen, S. (1991). Estimation and Hypothesis Testing of Cointegration Vectors in Gaussian vector Autoregressive Models. Econometrica.

Kapur, D. (2004) "Remittances: The New Development Mantra?": UN Conference on Trade and Development, United Nations, Geneva.

Kindle Berger CP (1965) Europe's postwar growth: the role of labor supply. Oxford University Press, New York, USA

Kevin, W. 2017. Do Remittances Improve Political Institutions? Evidence from Sub-Saharan Africa. Economic Modelling. 6: 65-75.

Jobst Koehler, Frank Laczko, Christine Aghazarm, Julia Schad (2010). Migration and Economic Crisis in European Union: Implication for policy. Research and Publication policy Division, IOM, Geneva.

Lisa A. 2012. Migration, Remittances and Household Welfare in Ethiopia. (un published)

Lipton, M., (1980) Migration from the Rural Areas of Poor Countries: The Impact on Rural Productivity and Income Distribution, "World Development", 8, pp. 1-24. 
Lopez, H., Molina, L. and Bussolo, M. (2007) Remittances and the real exchange rate. World Bank Policy Research Working Paper 4213, World Bank, Washington, DC.

Lucas, R.E. (2005), "International Migration and Economic Development," Stockholm: Expert Group on Development Issues, Swedish Ministry for Foreign Affairs.

Masron,T. and Subramaniam,Y. (2018),"Remittance-poverty in developing countries", International Journal of Development Issues, Vol. 17 No. 3, pp. 305-325. https://doi.org/10.1108/IJDI-04-2018-0054

Min B. Shrestha \& Khorshed Chowdhury, (2005). ARDL Modelling Approach to Testing the Financial Liberalization Hypothesis; University of Wollongong Economics Working Paper Series, WP 05-15.

Mikias Tilahun (2014). The Role of International Remittance on Economic Growth in Ethiopia: An Autoregressive Distributed Lag Approach, (Un published Master Thesis), Addis Ababa University. Addis Ababa, Ethiopia.

Moses A. Ofeh \& Ali T. Muandzevara. (2017). Investigating the Effects of Migrant Remittances on the Economic Growth of Cameroon. International Journal of Economics and Finance; Vol. 9, No. 2; 2017, 9 No. 2.: doi:10.5539/ijef. v9n2p58

Wondaferahu M., Tamasgen Y. \& Jibril H. (2015). Remittance with Economic Growth and Poverty Reduction in Ethiopia: Journal of RJIS, V 4, issue 5 ISSN 2250-3994.

Nisah \& Fayissa, B. (2011). The Impact of Remittances on Economic Growth and Development in Developing countries.

Narayan, P. K. (2005). The Saving and Investment Nexus for China: Evidence from Co- integration tests. Applied Economics, 37(17), 1979-1990.

Natnael Abraham, Wondaferahu Mulugeta, Minyahil Alemu, (2018) Predictors of National Saving: A Time Series Analysis to the Economy of Ethiopia: Journal of Economics and Sustainable Development www.iiste.org ISSN 2222-1700 (Paper) ISSN 2222-2855 (Online) Vol.9, No.13, 201826.

P. Phillips and P. Perron, (1988). Testing for a Unit Root in Time Series Regression. Bimetrika, 75, pp. 335-346.

Perron, P. and Vogelsang, T. (1992) Non stationarity and level shifts with an application to purchasing power parity, Journal of Business and Economic Statistics, 10, 301-320

Pesaran et al. (2001). Bounds Testing Approaches to The Analysis of Level Relationships. Journal of Applied Econometrics, 16, 289-326.

Pesaran, M. H. 1997. The Role of Economic Theory in Modeling the Long Run. The Economic Journal.

Pesaran, Smith and shin. (2001). Bound Testing Approaches to the Analysis of Long Run Relationships.

Ratha, D. (2003, 2005, 2014). The Impact of Remittances on Economic Growth and Poverty Reduction. Migration Policy Institute, Washington, DC.

Richard A., et al. (2017). The impact of remittance on economic growth of middle east and North Africa. World Bank document.

Robert Lucas \& Oded Stark. (1985). Motivations to Remit: Evidence from Botswana. Journal of Political Economy.

Ruiz - Arranz, M. 2006. Boosting Economic Growth. Institute of Development Studies. Retrieved from http:/www.idzl.org.

Sami B. M. and Mohamed S. B. (2012). Through Which Channels Can Remittances Spur. In Economics (6ed.p33). doi: http://dx.doi.org/10.5018/economics-ejournal.ja.2012.

Solow, R.M. and T.W. Swan (1956). "Economic Growth and Capital Accumulation', Economic Record, 32, pp. 334-61.

Stahl, C.W. and F. Arnold (1986), “Overseas Workers' Remittances in Asian Development": International Migration Review, 20 (4): 899-925.

Stock, J.H. (1994) Unit roots, structural breaks and trends. In Engle and McFadden Handbook.

Taban, S. (2010). An examination of the government spending and economic growth nexus for Turkey using the bound test approach. International Research Journal of Finance and Economics, 48, 184-193. Econometrics vol IV. Elsevier, pp. 2740-2841.

Tehseen Jawaid, S. and Raza, S. (2012), "Workers' remittances and economic growth in China and Korea: an empirical analysis", Journal of Chinese Economic and Foreign Trade Studies, Vol. 5 No. 3, pp. 185-193

Tassew D \& Rao 2016. The Impact of Remittances on Economic Growth in Ethiopia. Indian Journal of Commerce \& Management Studies. ISSN: 2249-0310 EISSN: 2229-5674.

Taylor JE, 1999. The New Economics of Labor Migration and the role of remittances in the migration process, International Migration. International Migration, Vol. 37, No 1, pp. 63-88.

Tesfaye G.W 2018. Impact of Remittance on Rural Household's Welfare: Evidence from North Wollo Zone, Guba lafto Woreda in Amhara Regional State, Using IV-Estimation Technique. Journal of Global Economics.

The World Bank (2006), Global Economic Prospective. Real Per Capita Growth and Remittances. Washington DC, USA.

Tchantchane Abdullatif Rodrigues, Gwendolyn Fortes \& Pauline Carolyne (2013). An empirical study of the impact of remittance, educational expenditure and investment on growth in the Philippines: Applied 
Econometrics and International Development, V.13-1

Uprety, D. (2017). The impact of remittances on economic growth in Nepal. Journal of Development Innovations, 114-134.

Waqas Javiad, 2017, Impact of Foreign Financial Inflow on Economic Growth of Pakistan. Do Remittances, Foreign Aid, and ODA Behave Similarly? Journal of Behavioral Economics, Finance, Entrepreneurship, Accounting and Transport. 2017, Vol. 5 No. 1, 10-18.

WB 2019; IMF 2019 and Forbes 2019. World Bank's Migration and Development Brief.

Williams, K. (2018). Are remittances good for economic growth? The role of political institutions. Applied Economics Letters, 25(1), 56-60.

World Bank, 2014. Migration and Development Brief. In: Washington DC. USA. Migration and Remittances Units, D.P.

Yasser Abdih et al. (2012). Remittances Channel and Fiscal Impact in the Middle East, North Africa, and Central Asia. IMF Working Paper.

\section{APPENDIX}

Table 1. Results of Augmented Dickey Fuller and Philips-Perron Test of I (1).

\begin{tabular}{|c|c|c|c|c|c|c|}
\hline \multirow[t]{2}{*}{ Variables } & \multicolumn{3}{|c|}{ ADF tests at I (1) } & \multicolumn{3}{|c|}{ PP tests at I (1) } \\
\hline & Intercept & $\begin{array}{l}\text { Intercept } \\
\text { +trend }\end{array}$ & None & Intercept & Intercept +trend & None \\
\hline$\Delta \ln R G D P$ & $-4.2279 * * *$ & $-4.4829 * * *$ & $-4.0613 * * *$ & $-3.6761 * *$ & $-4.3380 * *$ & $-4.0446 * * *$ \\
\hline$\Delta$ INR & $-8.4190 * * *$ & $-8.2929 * * *$ & $-5.8812 * * *$ & $-12.2039 * * *$ & $-11.7221 * * *$ & $-5.8910 * * *$ \\
\hline$\Delta \operatorname{lnFDI}$ & $-3.5068 * *$ & $-4.2003 * *$ & $-3.0803 * * *$ & $-4.6846 * * *$ & $-5.3143 * * *$ & $-4.4228 * * *$ \\
\hline$\Delta \ln$ GNS & $-7.1365 * * *$ & $-7.1149 * * *$ & $-2.7639 * * *$ & $-3.8378 * * *$ & $-3.8689 * *$ & $-6.1523 * * *$ \\
\hline$\Delta \ln R E M$ & $-5.9580 * * *$ & $-5.8474 * * *$ & $-5.8812 * * *$ & $-5.0139 * * *$ & $-4.9540 * * *$ & $-5.8910 * * *$ \\
\hline$\triangle \ln$ GCF & $-5.7975 * * *$ & $-6.7086 * * *$ & $-6.4531 * * *$ & $-5.7848 * * *$ & $-6.7620 * * *$ & $-6.4451 * * *$ \\
\hline$\Delta \operatorname{lnTOT}$ & $-4.6537 * * *$ & $-5.2158 * * *$ & $-5.8577 * * *$ & $-4.6458 * * *$ & $-5.2158 * * *$ & $-5.8577 * * *$ \\
\hline$\Delta \operatorname{lnDBT}$ & $-3.9573 * * *$ & $4.2482 * * *$ & $4.5145 * * *$ & $-4.0054 * * *$ & $-4.2417 * * *$ & $-4.5053 * * *$ \\
\hline
\end{tabular}

\begin{tabular}{|l|l|l|l|l|l|}
\hline \multicolumn{7}{|l|}{ Mackinnon (1996) Critical Values } \\
\hline & & Intercept & Intercept and trend & None & Significance \\
\hline \multirow{2}{*}{$\begin{array}{l}\text { Mackinnon } \\
\text { Critical }\end{array}$} & $\mathbf{1 \%}$ & $-\mathbf{3 . 6 2 6 7 8 4}$ & -4.226815 & -2.628961 & $* * *$ \\
\cline { 2 - 6 } Values & $\mathbf{5 \%}$ & $-\mathbf{2 . 9 4 5 8 4 2}$ & -3.536601 & -1.950117 & $* * *$ \\
\cline { 2 - 6 } & $\mathbf{1 0} \%$ & -2.611531 & -3.200320 & -1.611339 & $*$ \\
\hline
\end{tabular}

Source: E-views 11 output. 2019 and Mackinnon (1996) Critical Values for unit root tests.

Table 2. Selection-order criteria by Akaike Information Criterion

\begin{tabular}{|c|c|c|c|c|c|c|c|c|}
\hline \multicolumn{9}{|c|}{ Matrix list e(lags), actual lag presentation } \\
\hline \multicolumn{9}{|c|}{ e(lags) $[1,8]$} \\
\hline Variables & Lnrgdp & Lnrem & Lngcf & Lngns & Inr & Lntot & Infdi & Lndbt \\
\hline Lags & 1 & 1 & 1 & 0 & 2 & 2 & 2 & 1 \\
\hline
\end{tabular}

Source: Computation from Stata 13.

Table 3. Estimated Long Run Coefficients using the ARDL Approach

Levels Equation, Dependent variable LNRGDP, ARDL (1, 1, 1, 0, 2, 2, 2, 1) AIC Case III: Unrestricted Constant and No Trend $\quad$ Obs. $=37 \quad$ Dated: 1980-2018

\begin{tabular}{|c|c|c|c|}
\hline Variable & Coefficient & Std. Error & t-Statistic \\
\hline LNREM & $-0.089 * * *$ & 0.022935 & -3.892428 \\
\hline LNGCF & $0.792 * * *$ & 0.043711 & 18.13629 \\
\hline LNGNS & $0.108 * *$ & 0.049488 & 2.186955 \\
\hline INR & $0.003 * * *$ & 0.000798 & 4.670945 \\
\hline LNTOT & $-0.455 * * *$ & 0.071735 & -6.354213 \\
\hline LNFDI & $0.036 * * *$ & 0.007917 & 4.548307 \\
\hline LNDBT & $-0.172 * * *$ & 0.023098 & -7.473123 \\
\hline
\end{tabular}

Source: EViews 11, Own Computation, 2019.

Notes: $* * *, * \& *$ represent the probability value and significance at $1 \%, 5 \%$ and $10 \%$ respectively. 
Table 4. Error Correction Representation for the Selected ARDL Model

ARDL Error Correction Regression Time Span 1980-2018

Dependent Variable: $\triangle$ LNRGDP

Selected Model: ARDL $(1,1,1,0,2,2,2,1)$, AIC $\quad$ Obs. $=37$

\section{ECM Regression}

Case 3: Unrestricted Constant and No Trend

\begin{tabular}{|c|c|c|c|c|}
\hline Variable & Coefficient & Std. Error & t-Statistic & \\
\hline $\mathrm{C}$ & $4.961 * * *$ & 0.504449 & 9.836160 & \\
\hline$\triangle$ LNREM & $-0.050 * *$ & 0.021628 & -2.352724 & \\
\hline$\triangle \mathrm{LNGCF}$ & $0.772 * * *$ & 0.053599 & 14.40990 & \\
\hline$\Delta$ INR & $0.001 * * *$ & 0.000291 & 5.005987 & \\
\hline$\triangle$ INRL & $-0.001 * * *$ & 0.000364 & -5.080652 & \\
\hline$\Delta$ LNTOT & $-0.158 * *$ & 0.055389 & -2.861750 & \\
\hline$\triangle$ LNTOTL & $0.199 * *$ & 0.071062 & 2.805905 & \\
\hline$\Delta$ LNFDI & $0.026 * * *$ & 0.006605 & 4.073234 & \\
\hline$\triangle$ LNFDIL & $-0.015 * *$ & 0.006249 & -2.488453 & \\
\hline$\Delta$ LNDBT & $-0.154 * * *$ & 0.039043 & -3.962317 & \\
\hline $\operatorname{ECM~(-1)~}$ & $-0.724 * * *$ & 0.147345 & -4.916797 & \\
\hline R-squared & 0.914517 & \multirow{4}{*}{\multicolumn{2}{|c|}{$\begin{array}{l}\text { Mean dependent var } \\
\text { S.D. dependent var } \\
\text { Durbin-Watson stat }\end{array}$}} & 0.002044 \\
\hline Adjusted R-squared & 0.881639 & & & 0.070664 \\
\hline F-statistic & 27.81530 & & & 2.346416 \\
\hline Prob(F-statistic) & 0.000000 & & & \\
\hline
\end{tabular}

Source: own computation by EViews 11

Notes: $*, * * \& * *$ indicates that the series are significant at 10,5 and 1 percent, respectively. 